\title{
Lipiodol retention pattern predicts transarterial chemoembolization therapeutic effect in hepatocellular carcinoma
}

\author{
Margaretha Vianny*, Gunawan Santoso**, and Eddy Soedijanto**
}

\begin{abstract}
*Radiology Study Program, Faculty of Medicine, Diponegoro University/ Dr. Kariadi Hospital, Semarang **Department of Radiology, Faculty of Medicine, Diponegoro University/

Dr. Kariadi Hospital, Semarang

\section{BACKGROUND}

Hepatocellular carcinoma (HCC) incidence is increasing in Asia and Africa. Locoregional minimally invasive transarterial chemoembolization (TACE) is the palliative therapy of choice, improving survival rate. Adequate lipiodol dose calculation in TACE is necessary to produce good therapeutic effect. Lipiodol retention pattern can predict TACE therapeutic effect. This study aimed to determine correlation of lipiodol volume/tumor volume (L/V) ratio and lipiodol volume/tumor diameter (L/D) ratio with lipiodol retention pattern in post-TACE CT-scans of HCC patients.
\end{abstract}

\section{Correspondence}

dr. Margaretha Vianny, Sp.Rad. Radiology Study Program, Faculty of Medicine, Diponegoro University/ Dr. Kariadi Hospital, Semarang

Email:

margarethavianny@gmail.com

Univ Med 2015;34:52-60

DOI: 10.18051/UnivMed.2016.v35.52-60 pISSN: 1907-3062 / eISSN: 2407-2230

This open access article is distributed under a Creative Commons AttributionNon Commercial-Share Alike 4.0 International License

\section{METHODS}

This cohort prospective study was done from November 2013 to March 2014 on eighteen HCC patients with post-TACE therapy in Dr.Kariadi Hospital, Semarang, fullfilling inclusion and exclusion criteria. Lipiodol retention pattern was observed on 28 days post-TACE and classified as type I (lipiodol accumulation in tumor and surrounding area), type II (homogenous accumulation in tumor only), and type III (partial accumulation). The Spearman correlation test was used to determine any relationships between the various variables studied.

\section{RESULTS}

Spearman correlation test showed that lipiodol volume had significant moderate correlation with lipiodol retention pattern $(\mathrm{r}=-0.684 ; \mathrm{p}=0.002)$. Both L/V and L/D ratios had moderately significant correlation with lipiodol retention pattern $(\mathrm{r}=0.511 ; \mathrm{p}=0.030$; and $\mathrm{r}=0.518$; $\mathrm{p}=0.028$, respectively).

\section{CONCLUSION}

Correlations of $\mathrm{L} / \mathrm{V}$ ratio $\mathrm{L} / \mathrm{D}$ ratio with lipiodol retention pattern were both moderately significant. Lipiodol dose calculation based on L/V ratio is suggested considering the irregular three-dimensional form of the tumor, making volumetric measurement more appropriate.

Keywords: TACE, lipiodol, lipiodol retention, hepatocellular carcinoma 


\section{Pola retensi lipiodol meramalkan efek terapi lokoregional pada keganasan hepar}

\section{ABSTRAK}

\section{LATAR BELAKANG}

Karsinoma hepatoseluler (KHS) merupakan keganasan hepar dengan insidensi meningkat di Asia dan Afrika. Terapi lokoregional (Transarterial Chemoembolization) (TACE) dengan lipiodol dan kemoterapi menjadi terapi paliatif pilihan untuk meningkatkan angka kelangsungan hidup. Dosis lipiodol pada TACE harus adekuat agar efek terapi baik. Penelitian ini bertujuan menentukan adanya korelasi dan membandingkan rasio volume lipiodol/ volume tumor $(L N)$ dan volume lipiodol / diameter tumor $(L D)$ dengan pola retensi lipiodol pada CT-scan KHS dengan terapi TACE pada penderita KHS.

\section{METODE}

Desain penelitian adalah kohort prospektif menggunakan 18 penderita KHS dengan terapi TACE yang memenuhi kriteria inklusi dan eksklusi di RS Dr.Kariadi Semarang selama November 2013 hingga Maret 2014. Pola retensi lipiodol pada CT scan 28 hari pasca TACE diamati dan diklasifikasikan menjadi tipe I (akumulasi area tumor dan sekeliling tumor), II (akumulasi homogen pada tumor), dan III (akumulasi parsial). Uji korelasi Spearman digunakan untuk menguji hubungan berbagai variabel yang diteliti.

\section{HASIL}

Uji korelasi rank Spearman menunjukkan volume lipiodol berkorelasi sedang dengan pola retensi lipiodol ( $r=-$ 0,684; $p=0,002)$. Korelasi signifikan dengan kekuatan korelasi sedang juga ditemukan antara rasio L V dengan pola retensi lipiodol ( $r=0,511 ; p=0,030)$; dan antara rasio LD dengan pola retensi Lipiodol $(r=0,518 ; p=0,028)$.

\section{KESIMPULAN}

Korelasi antara rasio $L V$ dengan pola retensi lipiodol dan rasio $L D$ dengan pola retensi lipiodol sama-sama bermakna dan kekuatan korelasinya hampir sama. Penghitungan dosis lipiodol berdasarkan rasio LN lebih dianjurkan mengingat bentuk tumor irreguler dan memiliki dimensi ruang, sehingga lebih tepat pengukuran berdasarkan volume.

Kata kunci : TACE, lipiodol, pola retensi lipiodol, karsinoma hepatoseluler

\section{INTRODUCTION}

Hepatocellular carcinoma (HCC) is the most frequent primary malignancy of the liver, being number six among the most frequent neoplasms found in the whole world. It is more prevalent in males, with a male-to-female ratio of 4:2. ${ }^{(1-3)} \mathrm{HCC}$ incidence is highest in East Asia and sub-Saharan Africa. ${ }^{(3)}$ In Indonesia, HCC has a substantial incidence of $4.5 \%$, with a $6 \%$ mortality rate and fourth rank among cancers in males. This pattern of findings is associated with an approximately $80 \%$ incidence of viral hepatitis infection, and with liver cirrhosis and other HCC risk factors. ${ }^{(3,4)} \mathrm{HCC}$ ranks third among fatal cancers in the world, with a mortality rate of 600.000 per year and survival times of less than 8 months after diagnosis. ${ }^{(5-7)}$

Among the major therapeutic modalities of HCC are surgery, percutaneous radiofrequency ablation (PRFA), percutaneous ethanol injection (PEI), and transcatheter arterial chemo 
embolization (TACE), radiation therapy, and chemotherapy. ${ }^{(8-10)}$ In the last two decades, nonsurgical therapeutic interventions such as TACE have been inceasingly used for unresectable HCC. ${ }^{(9,10)}$ Lo et al. ${ }^{(11)}$ give the survival rate of HCC patients undergoing TACE as 57\%, which is higher than their $32 \%$ survival rate without TACE. The cumulative survival rate of HCC patients receiving TACE therapy is $90.6 \%$ with a median survival time of 46.6 months. ${ }^{(12)}$ Radiological investigations play an important role in establishing the diagnosis and treatment of HCC. Multiphasic CT scans and MRI are important imaging modalities in HCC diagnosis and follow-up, particularly to visualize contrast enhancement patterns. ${ }^{(13,14)}$ Other modalities that can be used are ultrasonography and laboratory investigation of the alpha-fetoprotein serum marker. ${ }^{(15)}$

Transcatheter arterial chemoembolization is a minimally invasive chemotherapeutic method applied to the target tumor via the hepatic artery, followed by embolization of its branches supplying blood to the tumor. ${ }^{(16)}$ The combination of chemotherapy with an embolant places a higher concentration of the chemotherapeutic agent in longer contact with the target organ and reduces systemic effects. ${ }^{(17)}$

Transcatheter arterial chemoembolization combined with lipiodol as embolant has been reported to be one of the most effective palliative treatment for HCC. ${ }^{(11,12)}$ The dose of lipiodol should be adequate to yield good therapeutic effect, but it must not be excessive, since the lipiodol may undergo reverse flow to the normal liver parenchyma, decreasing liver function and resulting in liver cirrhosis. There is no agreement yet in the literature on the volume of lipiodol to be used in TACE. To date the dose has been based on tumor diameter or maximally $20-30 \mathrm{~mL}$ for a tumor diameter larger than $10 \mathrm{~cm}$. Apart from the diameter, a tumor has shape and volume, therefore the lipiodol dose in the tumor does not depend exclusively on its diameter. ${ }^{(18)}$ The lipiodol accumulation or retention pattern in the tumor area on post-TACE CT scans are reported to play a role in predicting the efficacy of TACE for HCC. ${ }^{(19)}$ The disease free survival rate is higher and the recurrence rate lower in patients with a lipiodol accumulation pattern in the area surrounding the tumor on post-TACE CT scans. ${ }^{(10)}$

There have been several previous studies on the relationship between TACE-treated HCC and lipiodol retention pattern on CT scan. Kawaguchi et al. ${ }^{(10)}$ investigated the lipiodol accumulation pattern in post TACE HCC patients in connection with therapeutic efficacy. They found that the lipiodol accumulation pattern evaluated by CT scans immediately after TACE was a strong indicator of TACE therapeutic efficacy. Matsuo et al. ${ }^{(20)}$ conducted a study to find the optimal lipiodol dose based on lipiodol accumulation pattern and histopathologic picture. They found a correlation of lipiodol accumulation on CT scan with degree of necrosis on histologic examination and suggested an optimal lipiodol dose $\mathrm{D} \geq \mathrm{d}$ (if tumor diameter $\mathrm{d} \leq 5 \mathrm{~cm}$ ) with a maximal dose of $10 \mathrm{~mL}$. Cheng et al. ${ }^{(18)}$ conducted an investigation on lipiodol dose adjustment in TACE on the basis of the HCC blood supply on CT scan, and found that the lipiodol dose may be determined from the blood supply pattern and tumor diameter. The lipiodol dose was adjusted to tumor diameter or 1.5 times the tumor diameter and maximally 20 $\mathrm{mL}$ (tumor diameter $\leq 10 \mathrm{~cm}$ ) up to $30 \mathrm{~mL}$ (tumor diameter $>10 \mathrm{~cm}$ ). The present study is the first to be conducted on the relationship of lipiodol volume used in TACE, tumor volume, tumor diameter, and lipiodol retention pattern.

The purpose of this study was to determine any correlation of, on the one hand, the TACE lipiodol volume to tumor volume ratio and the lipiodol volume to tumor diameter ratio as measured on baseline CT scan, with on the other hand, the lipiodol retention pattern on CT scan evaluated 28 days post-TACE, in accordance with the $\mathrm{HCC}$ evaluation protocol. Evaluation of the lipiodol retention pattern may be predictive of antitumor effect or TACE success rate. This study did not involve patient survival rate or histopathologic picture of the lesion. 


\section{METHODS}

\section{Design of study}

This study was observational analytic, of prospective cohort design without controls. The study was carried out in Dr. Kariadi Central General Hospital, Semarang, starting from October 2013 until March 2014.

\section{Study subjects}

The study subjects were patients with a diagnosis of HCC based on CT scan results, in accordance with the criteria of the European Association for the Study of the Liver (EASL) and European Organisation for Research and Treatment of Cancer (EORTC). The diagnosis of HCC was based on the size of the primary lesion, i.e. the presence of a hepatic mass of more than $2 \mathrm{~cm}$ with characteristic arterial vascularization visible on at least two radiological modalities (USG, CT, MRI) or the presence of a hepatic mass identified by one radiological modality and increased serum alphafetoprotein (AFP) of $>400 \mathrm{ng} / \mathrm{mL}$. ${ }^{(21-23)}$

The diagnosis of HCC may be established by a specialist in radiology or internal medicine. The study subjects were HCC patients meeting the following inclusion criteria: i) no tumor invasion to the portal vein and inferior vena cava, or other metastases; ii) $\mathrm{Hb} \geq 9 \mathrm{~g} / \mathrm{dL}$, leukocyte count $\leq 11.000$, serum creatinine $<1.5 \mathrm{mg} / \mathrm{dL}$, total bilirubin $\leq 3 \mathrm{mg} / \mathrm{dL}$; iii) Child-Pugh criteria $\mathrm{A}$ or $\mathrm{B}$, i.e. $\mathrm{HCC}$ with or without decreased liver function that can be compensated by the patient, ${ }^{(24)}$ and iv) a CT scan picture showing rapid enhancement (increase in Hounsfield Unit score) in the arterial phase when the contrast agent starts to fill the hepatic artery followed by wash out (rapid decrease in Hounsfield Unit score) in the portovenous and equilibrium phase when the contrast has entered the portal vein and inferior vena cava. The exclusion criteria for the study subjects were: i) HCC subjects not having the CT scan exactly 28 days post-TACE; ii) presence of arteriovenous fistulae in HCC vascularization.
The sample size was determined using the formula for sample size calculation for proportions with proportion of TACE efficacy of 0.84 , at $\alpha=0.05$, yielding a minimal sample size of 18 . The study sample was selected by consecutive non-random sampling, on the basis of patient admittance at Dr. Kariadi Hospital, Semarang.

\section{Determination of $\mathrm{HCC}$ diameter and volume on CT scan}

Tumor diameter and volume before TACE therapy were measured by multiphase CT scan in the cranio-caudal direction using nonionic contrast medium at a concentration of $300 \mathrm{mg} /$ $\mathrm{mL}$, a dose of $1.5-2 \mathrm{~mL} / \mathrm{kgBW}$, with maximal dose of $150 \mathrm{~mL}$. The contrast medium was administered by intravenous injection in the extremities or by a $20 \mathrm{G}$ cannula, using the Mallinckrodt Optivantage power injector at flow rates of $4-5 \mathrm{~mL} / \mathrm{s}$. The scans were performed for the whole hepatic region in the early arterial phase (25 s), late arterial phase (35 s), portal phase (60-70 s), and equilibrium phase (120-180 s), starting at the time of contrast injection. Evaluation of the scan results was by multiplanar reconstruction using a Siemens Syngo DynaCT work station. CT parameters: collimation $64 \mathrm{x}$ $0.6 \mathrm{~mm}$, slice thickness $3 \mathrm{~mm}$, image reconstruction increment $0.625 \mathrm{~mm}, 120 \mathrm{kV}$, 200-250 mAs.

Tumor diameter (D) was measured by drawing a center line through the widest area of the HCC tumor image as seen on CT scan and was expressed in centimeters $(\mathrm{cm})$. Tumor volume $(\mathrm{V})$ was measured by manual drawing using a computer mouse following the tumor contour lines in all sections or slices, then the area of the lesion was calculated by computer software to yield the tumor volume in cubic centimeters $\left(\mathrm{cm}^{3}\right)$.

\section{Lipiodol volume in TACE}

TACE was performed according to standard procedures using a DSA ArtisZ (Siemens) fluoroscopy instrument with arterial access via 
the common fermoral vein using a $6 \mathrm{~F}$ sheath. Access to the celiac trunk was achieved using a Simmons $5 \mathrm{~F}$ catheter followed by a $2.7 \mathrm{~F}$ microcatheter to access the lobar or segmental artery that constitutes the feeding artery to the tumor. After catheter placement, the chemotherapeutic drug was injected and embolization was done using lipiodol until a substatic flow was obtained, with minimal tumor blush, when the lipiodol had occupied the whole tumor area and the injected lipiodol flow slowed down. The injection was performed manually to minimize retrograde flow to the arterial vascularization of other segments.

The volume of lipiodol (L) was obtained from the amount of lipiodol administered in TACE therapy until circulatory stasis was seen in the HCC (in $\mathrm{mL}$ ) or maximally $30 \mathrm{~mL}$. The standard optimal lipiodol dose according to Matsuo et al. ${ }^{(20)}$ is $\mathrm{D} \geq \mathrm{d}$ (for tumors $\leq 5 \mathrm{~cm}$ ); and maximally $10 \mathrm{~mL}$. On the other hand, the lipiodol dose according to Cheng et al. ${ }^{(18)}$ is adjusted to tumor diameter or 1.5 times tumor diameter, and maximally $20 \mathrm{~mL}$ (for tumors $\leq 10 \mathrm{~cm}$ ) up to 30 $\mathrm{mL}$ (for tumors $>10 \mathrm{~cm}$ ).

The ratio of lipiodol volume to tumor volume (L/V ratio) was calculated by comparing the lipiodol volume administered during TACE to the tumor volume on diagnostic CT scan, expressed in $\mathrm{mL} / \mathrm{cm}^{3}$. The ratio of lipiodol volume to HCC tumor diameter (L/D ratio) was determined by comparison of lipiodol volume administered during TACE to HCC tumor diameter on diagnostic CT scan, expressed in $\mathrm{mL} / \mathrm{cm}$.

\section{Lipiodol retention pattern}

The lipiodol retention pattern was evaluated on CT scans 28 days post-TACE using procedures, and contrast medium amounts and concentrations similar to those used for CT scans before TACE therapy. The observed lipiodol retention pattern was then classified into 3 types (Figure 1). ${ }^{(10)}$

Type I, lipiodol accumulation in the whole tumor and surrounding area. Lipiodol and chemotherapeutic agent fill the whole tumor and surrounding area. According to studies, patients with this type of retention have higher survival rates. Type II, homogenous accumulation in whole HCC tumor area. In this type, the lipiodol and chemotherapeutic agent can fully enter the tumor, with an area of tumor necrosis of up to $98 \%$, and is considered to represent an adequate antitumor effect. Type III, accumulation in the HCC tumor area only. This type is correlated with a less than optimal distribution of the chemotherapeutic agent.

\section{Data analysis}

The Spearman correlation test was used to determine any relationships between the various variables studied (lipiodol volume, tumor volume, tumor diameter and their ratios versus lipiodol retention pattern). The correlation was considered statistically significant if $\mathrm{p}<0.05$.
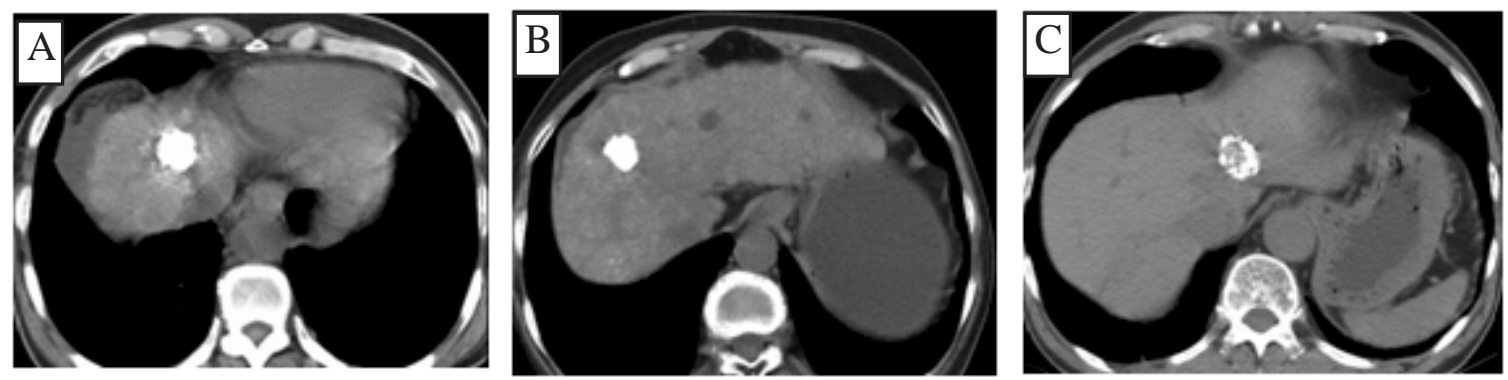

Figure 1. Classification of lipiodol retention in HCC patients on TACE. ${ }^{(10)}$

A. Type I : accumulation in whole HCC tumor and surrounding area

B. Type II : homogenous accumulation throughout the HCC tumor area C. Type III : accumulation in part of HCC tumor area only 
Table 1. Lipiodol volume, tumor volume, tumor diameter, lipiodol volume/HCC tumor volume ratio, and lipiodol volume/HCC tumor diameter ratio, by lipiodol retention pattern

\begin{tabular}{lccc}
\hline & \multicolumn{3}{c}{ Lipiodol retentionp atterm } \\
\cline { 2 - 4 } & Type I & Type II & Type III \\
\hline Lipiodol volume $(\mathrm{mL})$ & 7 & 14 & 15 \\
Tumor wolume $\left(\mathrm{cm}^{5}\right)$ & 3.90 & 102.88 & 474.50 \\
Tumor d am eter $(\mathrm{cm})$ & 2.60 & 6.10 & 10.30 \\
Lipiodol volume $/$ tum or volume ratio $\left(\mathrm{mL} / \mathrm{cm}^{2}\right)$ & 1.28 & 0.11 & 0.04 \\
Lipiodol volume $/$ tum or diameter rati $(\mathrm{mL} / \mathrm{am})$ & 2.64 & 2.07 & 1.83 \\
\hline
\end{tabular}

*Values are median

\section{RESULTS}

During the study period $18 \mathrm{HCC}$ patients were encountered who met the research criteria. The median age of the study sample was 59 years, with minimum of 46 years and maximum of 77 years. The age distribution of the study sample was as follows: $\leq 50$ years 2 subjects (11\%), 51-60 years 10 subjects (55\%), 61-70 years 3 subjects (17\%), and $>70$ years 3 subjects (17\%). Most of the study subjects were male, 16 in total (89\%), while females totaled only 2 (11\%).

The 28-day post-TACE CT scans showed variable lipiodol retention patterns, comprising type I (lipiodol accumulation in whole tumor and surrounding area), type II (homogenous accumulation in tumor), and type III (partial accumulation in tumor). The most frequent lipiodol retention pattern was of type III, accounting for 13 subjects (72.2\%), followed by type I with 3 subjects (16.7\%), and type II with 2 subjects $(11.1 \%)$.

In this study the median tumor volume was $231.38 \mathrm{~cm}^{3}$, the largest tumor volume was 668.2 $\mathrm{cm}^{3}$ and the smallest $3.7 \mathrm{~cm}^{3}$, while the median tumor diameter was $8.18 \mathrm{~cm}^{3}$, the largest diameter $14.24 \mathrm{~cm}^{3}$ and the smallest $2.5 \mathrm{~cm}^{3}$. The maximal lipiodol volume in this study was 25 $\mathrm{mL}$, administered to one tumor with a volume of $668.2 \mathrm{~cm}^{3}$ and a diameter of $13.8 \mathrm{~cm}$, and one with a volume of $522.25 \mathrm{~cm}^{3}$ and diameter of $10.3 \mathrm{~cm}$. The minimum lipiodol volume in this study was $5 \mathrm{~mL}$, administered to one tumor with a volume of $3.7 \mathrm{~cm}^{3}$ and a diameter of $2.5 \mathrm{~cm}$.
The lipiodol retention types differed in their median $\mathrm{L} / \mathrm{V}$ and $\mathrm{L} / \mathrm{D}$ ratios. The highest $\mathrm{L} / \mathrm{V}$ ratio of $1.28 \mathrm{~mL} / \mathrm{cm}^{3}$ was found in lipiodol retention pattern type I, followed by type II with a ratio of $0.11 \mathrm{~mL} / \mathrm{cm}^{3}$, while the lowest ratio was for type III, namely $0.04 \mathrm{~mL} / \mathrm{cm}^{3}$. The $\mathrm{L} / \mathrm{D}$ ratio had a similar data distribution, with the highest L/D ratio in lipiodol retention pattern type I, namely $2.64 \mathrm{~mL} / \mathrm{cm}$, followed by type II with $2.07 \mathrm{~mL} /$ $\mathrm{cm}$, and the lowest in type III with $1.83 \mathrm{~mL} / \mathrm{cm}$ (Table 1).

There was a significant moderately moderate negative correlation of lipiodol volume, tumor volume, and tumor diameter with lipiodol retention pattern $(\mathrm{r}=-0.68, \mathrm{p}=0.002 ; \mathrm{r}=-0.63, \mathrm{p}=0.005$; and $\mathrm{r}=-0.67, \mathrm{p}=0.002$, respectively). However, the correlation of lipiodol volume/HCC tumor volume and lipiodol volume/tumor diameter ratios with lipiodol retention pattern was positive significant of moderate correlation $(r=0.51 ; p=0.030)$ and negative moderate correlation $(\mathrm{r}=-0.53 ; \mathrm{p}=0.028)$ (Table 2).

Tabel 2. Correlation of lipiodol volume/tumor volume (L/V) and lipiodol volume/tumor diameter (L/D) with lipiodol retention pattern

\begin{tabular}{lcc}
\hline \multicolumn{1}{c}{ Variable } & \multicolumn{2}{c}{ Lipiodol retention pattern } \\
& r & p va hue \\
\hline Lipiodol volum e & -0.68 & 0.002 \\
Tum or volum e & -0.63 & 0.005 \\
Tum or diam eter & -0.67 & 0.002 \\
LN r atio & 0.51 & 0.030 \\
L/D ratio & 0.53 & 0.028 \\
\hline
\end{tabular}




\section{DISCUSSION}

This study involved 18 subjects consisting of 16 males $(89 \%)$ and 2 females (11\%), with the youngest 46 years of age and the oldest 77 years, and the majority between 51-60 years. This agrees with the literature, in that HCC incidence is higher in males than in females, with a ratio of 5:1 and mean age of 50-70 years. ${ }^{(3,7)}$ Altekruse et al. ${ }^{(1)}$ and the American Cancer Society revealed that the higher HCC incidence in males is associated with behavior or life style as risk factors for $\mathrm{HCC}$, such as alcohol consumption, smoking, and drug abuse by injection. ${ }^{(1)}$

The tumor with the largest volume in this study did not always have the largest tumor diameter or received the largest lipiodol volume, whereas the largest tumor diameter also did not always have the largest tumor volume and the largest lipiodol volume. This was caused by the irregular tumor shape, such that increases in tumor volume and tumor diameter were not always proportional, but tended to be linear in the diagram, and this was also the case with the lipiodol volume administered to the tumor.

The lipiodol retention pattern in the tumors varied from type I to type III. Of the 18 study subjects, most had type III retention patterns, totalling 13 subjects $(72.22 \%)$, followed by type I with 3 subjects (16.67\%), and type II with 2 subjects $(11.11 \%)$. These findings differed from the results of Kawaguchi et al. ${ }^{(10)}$ who found that in $117 \mathrm{HCC}$ tumors the most frequent retention pattern was of type II (42\%), followed by type I $(35 \%)$, the least frequent being type III (22\%). In our study the finding of type III as the most frequent retention type may have been caused by the large tumor size in the majority of study subjects and the negative correlation of lipiodol volume, tumor volume, and tumor diameter with lipiodol retention pattern. Therefore the larger lipiodol volume, tumor volume, and tumor diameter, tended to result in low lipiodol retention (type III). The larger tumors will form arteriovenous microfistulae, such that the lipiodol entering the hepatic artery cannot accumulate but on the contrary will flow into the venous system. Our study results showed a significant relationship of lipiodol volume/tumor volume ratio and lipiodol volume/tumor diameter ratio with lipiodol retention pattern. The positive correlations showed that higher L/V and L/D ratios tend to yield type I retention, where lipiodol fills the whole tumor and surrounding area, while lower $\mathrm{L} / \mathrm{V}$ and $\mathrm{L} / \mathrm{D}$ ratios tend to result in type III retention. Therefore, with increasingly higher $\mathrm{L} / \mathrm{V}$ and $\mathrm{L} / \mathrm{D}$ ratios there will be an optimal lipiodol accumulation in the tumor and adequate therapeutic results. However, it should be borne in mind that according to the literature the maximal dose of lipiodol is $30 \mathrm{~mL}$. The lipiodol dose should be adequate to yield good therapeutic effects, but should not be excessive, since the lipiodol may then undergo a reverse flow to the normal liver parenchyma, thus decreasing liver functions, resulting in liver cirrhosis. ${ }^{(18)}$

Lipiodol in TACE functions as anticancer drug transporter, and acts to enhance the antitumor effect of anticancer drugs. It may also act as embolant, causing ischemia and lymphatic drainage problems, finally resulting in tumor necrosis. Decreasing retention of lipiodol by the tumor (approaching type III retention) indicates less than optimal distribution of the chemotherapeutic agent, with a small area of necrosis, indicative of a poor therapeutic response. Increasing lipiodol retention (approaching type I retention) indicates optimal distribution of the chemotherapeutic agent, with a large area of necrosis and excellent therapeutic response..$^{(9,10)}$ Some of the factors that may influence the lipiodol retention pattern are among others: tumor size, volume of lipiodol administered, vascular permeability, lymphatic flow, and tumor necrosis. ${ }^{(9)}$ The lipiodol retention pattern has been reported to play a role in predicting the effect of TACE on HCC. ${ }^{(19)}$ The diseasefree survival rate is higher and the recurrence rate lower in patients with type I lipiodol accumulation pattern. ${ }^{(10)}$ 
The type I lipiodol retention pattern is obtained from the higher median L/V and L/D ratios in comparison with the other types of retention $\left(\mathrm{L} / \mathrm{V}\right.$ ratio $=1.28 \mathrm{~mL} / \mathrm{cm}^{3} ; \mathrm{L} / \mathrm{D}$ ratio $=$ $2.64 \mathrm{~mL} / \mathrm{cm}$ ). The type II lipiodol retention pattern has lower median $\mathrm{L} / \mathrm{V}$ and $\mathrm{L} / \mathrm{D}$ ratios of $0.11 \mathrm{~mL} / \mathrm{cm}^{3}$ and $2.09 \mathrm{~mL} / \mathrm{cm}$, respectively; while the type III retention pattern has the lowest median $\mathrm{L} / \mathrm{V}$ and $\mathrm{L} / \mathrm{D}$ ratios of $0.04 \mathrm{~mL} / \mathrm{cm}^{3}$ and $1.83 \mathrm{~mL} / \mathrm{cm}$, respectively. This picture also supports the positive correlation results, where higher $\mathrm{L} / \mathrm{V}$ and L/D ratios tend to approach type I retention patterns. Therefore high $\mathrm{L} / \mathrm{D}$ and $\mathrm{L} /$ $\mathrm{V}$ ratios are expected to increase the effectivity of curative treatment. The retention patterns that are considered good are types I and II, with L/V ratios in the range of $0.11-1.28 \mathrm{~mL} / \mathrm{cm}^{3}$ and $\mathrm{L} /$ $\mathrm{D}$ ratios from 2.07 to $2.64 \mathrm{~mL} / \mathrm{cm}$. The $\mathrm{L} / \mathrm{D}$ ratio in the present study was higher than that of Cheng et al. ${ }^{(18)}$ who stated that lipiodol volumes equal to 1.5 times the tumor diameter yield curative effects. However, in their study the lipiodol dose was not determined from tumor volume or $\mathrm{L} / \mathrm{V}$ ratio.

The correlation values of $\mathrm{L} / \mathrm{V}$ and $\mathrm{L} / \mathrm{D}$ with lipiodol retention are almost identical. In spite of this, dose calculation on the basis of volume is superior to tumor size measurement, because it can compensate for actual tumor shape, particularly in irregularly-shaped tumors that cannot be represented by their largest diameter only. ${ }^{(25,26)}$ Initially, the WHO issued guidelines for tumor size determination using the largest diameter of the tumor. In line with technological advances, Prasad et al. ${ }^{(26)}$ reported on HCC volume measurement using three-dimensional CT that can give a true picture of post-TACE tumor response, particularly for tumors of irregular shape. The European Organization for Research \& Treatment in Oncology and the National Cancer Institute of the United States also recommend the technique of tumor volume determination by CT scan for the evaluation of TACE. ${ }^{(24,25,27)}$ Therefore it can be stated that lipiodol dose calculation based on L/V ratio is better for succesful TACE. However, in hospitals where tumor volume determination by CT scan reconstruction software cannot be done, the L/ $D$ ratio may still be used, as it is correlated with $\mathrm{L} / \mathrm{V}$.

The significant correlations of $\mathrm{L} / \mathrm{V}$ and $\mathrm{L} /$ $D$ ratios with lipiodol retention pattern indicate the importance of lipiodol dose calculation based on volume as well as tumor diameter, with the expected formation of good lipiodol retention patterns on 28-day post-TACE CT scans. The CT scan is an important imaging modality for tumor diagnosis, determination of tumor diameter and volume, and evaluation of HCC response on TACE therapy.

Our study did not perform sample stratification according to tumor size, which might have resulted in different and varying L/ $\mathrm{V}$ and $\mathrm{L} / \mathrm{D}$ ratios, depending on the size of the tumors. In the future we expect to conduct studies on HCC tumors with tumor size stratification. Larger tumor size tends to lead to arterio-venous microfistula formation, such that the lipiodol entering the hepatic artery cannot accumulate but is drained by the venous system, resulting in type III lipiodol retention. ${ }^{(9)}$ To obtain good retention patterns, a larger lipiodol dose should be used, but limited by the maximal dose. In large tumors the maximal dose is usually insufficient to fill the whole tumor area, causing circulatory stasis. This causes optimal differences in L/V and L/D ratios between large and small tumors. Furthermore, we expect future studies to allow us to deduce the therapeutic efficacy from the patient's clinical improvement and liver function test results.

\section{CONCLUSION}

The correlations of both $\mathrm{L} / \mathrm{V}$ ratio and L/D ratio with lipiodol retention pattern were significant and of similar strengths. Lipiodol retention pattern can predict TACE therapeutic efficacy in HCC. 


\section{REFERENCES}

1. Altekruse S, McGlynn K, Reichman M. Hepatocellular carcinoma incidence, mortality, and survival trends in the United States from 1975 to 2005. J Clin Oncol 2009;27:1485-91.

2. Siegel R, Naishadham D, Jemal A. Cancer statistics 2013. CA Cancer J Clin 2013;63:1130 .

3. Venook AP, Papandreou C, Furuse J, et al. The incidence and epidemiology of hepatocellular carcinoma: a global and regional perspective. Oncologist 2010;15 Suppl 4:S5-13.

4. Gomaa AI, Khan SA, Toledano MB, et al. Hepatocellular carcinoma: epidemiology, risk factors and pathogenesis. World J Gastroenterol 2008;21;14:4300-8.

5. Parkin DM, Bray F, Ferlay J, et al. Global cancer statistics, 2002. CA Cancer J Clin 2005;55:74108.

6. Ferlay J, Shin HR, Bray F, et al. Estimates of worldwide burden of cancer in 2008: GLOBOCAN 2008. Int J Cancer 2010;127: 2893-917.

7. Gani RA. Faktor risiko dan mekanisme karsinogenesis hepatoma. Semarang: Gastroenterohepatology Update II Clinical application in Gastroenterohepatology;2012.

8. Marrero J. Current treatment approaches in HCC. Clin Adv Hematol Oncol 2013;11 Suppl 5:S15-8.

9. Adam A, Mueller PR. Interventional radiological treatment of liver tumors. New York: Cambridge University Press;2009.

10. Kawaguchi T, Ohkawa K, Imanaka K, et al. Lipiodol accumulation and transarterial chemo embolization efficacy for HCC patients. Hepatogastroenterol 2012;59:219-23.

11. Lo CM, Ngan H, Tso WK, et al. Randomized controlled trial of transarterial lipiodol chemoembolization for unresectable hepatocellular carcinoma. Hepatol 2002;35: 1164-71.

12. Kasai K, Ushio A, Kasai Y, et al. Therapeutic efficacy of transarterial chemo-embolization with a fine-powder formulation of cisplatin for hepatocellular carcinoma. World J Gastroenterol 2013;19:2242-8.

13. Takayasu K, Arii S, Ikai I, et al. Prospective cohort study of transarterial chemoembolization for unresectable hepatocellular carcinoma in 8510 patients. Gastroenterol 2006;131:461-9.

14. Cruite I, Tang A, Sirlin CB. Imaging-based diagnostic systems for hepatocellular carcinoma. Am J Roentgenol 2013;201:41-55.
15. Bialecki ES, Bisceglie AM. Diagnosis of hepatocellular carcinoma. HPB 2005;7:26-34.

16. Pentecost M. Interventional therapies for hepatic malignancy. In: Baum S, Pentecost M, editors. Abram's angiography interventional radiology. Philadelphia: Lippinott Wiliams \& Wikins;2006. p.516-24.

17. Shin WS. The current practice of transarterial chemoembolization for the treatment of hepatocellular carcinoma. Korean J Radiol 2009; 10:425-34

18. Cheng HY, Xu AM, Chen D, et al. Adjustment of lipiodol dose according to tumor blood supply during the transcatheter arterial chemoembolization for large hepatic carcinoma by multidetector helical CT. Chinese J Oncol 2004;25:186-9.

19. Lim HS, Jeong YY, Kang HK, et al. Imaging features of hepatocellular carcinoma after transcatheter arterial chemoembolization and radiofrequency ablation. Am J Roentgenol 2006; 187:341-9.

20. Matsuo N, Uchida H, Sakaguchi H, et al. Optimal lipiodol volume in transcatheter arterial chemoembolotherapy for hepatocellular carcinoma: study based on lipiodol accumulation patterns and histopathologic findings. Semin Oncol 1997;24 Suppl 6:S67-70.

21. Llovlet JM, Ducreux M, Lencioni R, et al. EASL-EORTC clinical practice guidelines: management of hepatocellular carcinoma. J Hepatol 2012;56: 908-43.

22. Talwalkar JA, Gores GJ. Diagnosis and staging of hepatocellular carcinoma. Gastroenterol 2004;127 Suppl 1:S126-32.

23. Omata M, Lesmana LA, Tateishi R, et al. Asian Pacific Association for the Study of the Liver consensus recommendations on hepatocellular carcinoma. Hepatol Int 2010;4:439-74.

24. Jelic S, Sotiropoulos GC. Hepatocellular carcinoma: ESMO clinical practice guidelines for diagnosis, treatment and follow-up. Ann Oncol 2010;21 Suppl 5:S59-64.

25. Zhang JW, Feng XY, Liu HQ, et al. CT volume measurement for prognostic evaluation of unresectable hepatocellular carcinoma after TACE. World J Gastroenterol 2010;16:2038-45.

26. Prasad SR, Jhaveri KS, Saini S, et al. CT tumor measurement for therapeutic response assessment: comparison of unidimensional, bidimensional, and volumetric techniques initial observations. Radiol 2002;225:416-9.

27. Guan YS, Hu Y, Liu Y. Multidetector-row computed tomography in the management of hepatocellular carcinoma with transcatheter arterial chemoembolization. J Gastroenterol Hepatol 2006;21:941-6. 